\title{
Yield and Quality of Irrigated Tobacco Under Subhumid Conditions
}

\author{
Modesto Capiel and Aurelio Sierra Bracero ${ }^{1}$
}

\section{INTRODUCTION}

Tobacco is produced on a Mountain Belt of Puerto Rico extending from the Southeast to the Northwest. The cigar-filler type predominates and centers in this Belt from San Lorenzo to Utuado. Chewing tobacco is also produced on a much smaller scale in the drier areas of the Belt.

Traditionally, tobacco has generally been grown by the lower-income farmers on many of our less fertile and/or more eroded soils of the interior part of the Island. Being a clean-cultivated crop, generally planted on the peak of the rainfall season, soil erosion is very likely. In order to insure a good stand, the planting season is established to correspond with probability of adequate rainfall along the growth period.

Acosta et al. $(1)^{2}$ studied the response of cigar-filler tobacco to different planting dates. Although yields were not closely related to rainfall, the lowest were associated with growth periods of least-rainfall intensity, although accompanied by days of lower evaporative demands (shorter and cooler). On the other hand the highest yield was obtained from a May planting, when the growth period was characterized with increasingly longer days without excessive rainfall, and possibly greater evaporative demands. The May-planted crop of variety P. R. 1-60 produced over 17 hundredweights per cuerda, ${ }^{3}$ better by more than 50 percent the Island mean yield. The Tobacco was grown on rather heavy soil with a moderate to a steep slope.

The possibility of growing tobacco on soils less subject to erosion, under irrigation and more favorable environmental conditions during the growth period, should be investigated. This may be one answer to making tobacco a more profitable crop, even though possibly for a reduced number of farmers. At the same time, by introducing the irrigation practice, the production of other short season crops that could be grown in rotation with tobacco might be made economically feasible.

Parks et al. (4) reported that the quality of the dark tobacco leaf in Tennessee increased with irrigation under increased nitrogen fertilization.

${ }^{1}$ Associate Soil Scientist and formerly Research Assistant, Gurabo Substation, Agricultural Experiment Station, Mayagüez Campus, University of Puerto Rico, Río Piedras, P.R.

2 Numbers in parentheses refer to Literature Cited, p. 294.

3 A cuerda is equal to 0.97 acre or 0.39 hectare. 
The greatest response to irrigation was observed in the 1956 and 1957 crops, when the number of dry days between June and August was greatest.

In irrigated tobacco, the quality of the irrigation water may affect the chemical composition of the tobacco leaf and its combustibility. Ramakrishna and his coworkers (5) from India report contrasting results by using irrigation water of different chloride and total mineral concentration. Although the high chloride content of the irrigation water did not lower the yield, the leaves had a poor burn and were high in chloride content. The leaves also exhibited low potassium and phosphorus uptake when compared with tobacco irrigated with water of a lower chloride content. The magnesium uptake was enhanced by high chloride in the irrigation water. There was found, however, little dependence of the chemical composition of the leaf on the soil mineral composition.

A high chloride content of the tobacco leaf leads to a higher osmotic value of the cell sap, contributing to a greater leaf turgidity and to a more enhanced growth than otherwise. Manzano (3) pointed out that an increase in the osmotic pressure of the tobacco leaf, as a result of higher chloride content, led to a highly-cutinized leaf reducing the combustibility of the leaf and producing a rather harsh or tart smoke.

This paper presents the results of two experiments carried out to evaluate the influence of different irrigation regimes on the yield and quality of two varieties of filler tobacco.

\section{EXPERIMENTAL METHODS AND PROCEDURES}

The experiment was conducted at the Gurabo Substation farm, Gurabo, P.R. This area lies in the Turabo Valley at an elevation of around $52 \mathrm{~m}$. The mean annual precipitation (65-year average) is $160 \mathrm{~cm}$., about 42 percent of it being received in 90 days, generally along in August to October. The drier season generally lasts 100 to 120 days. It occurs along January to April for which the mean precipitation is from 20 to $23 \mathrm{~cm}$. The mean annual temperature is $25^{\circ} \mathrm{C}$. with an average range of $6^{\circ} \mathrm{C}$. between the mean temperatures of the warmest and the coldest months of the year. The daily temperature range is much greater, reaching as much as $10^{\circ} \mathrm{C}$.

The surface soil consists of a grayish brown silty-clay loam mixed with some coarse material deposited from occasional overflows of a nearby stream. It gets a little heavier with depth, having some rust, indicated by brown and gray mottling. At 60 to $75 \mathrm{~cm}$. below the surface a coarse sand and gravelly layer appears, though intermixed with mottled rust-brown clay.

The 0 to $15-\mathrm{cm}$. layer of soil has a cation exchange capacity of around 23 meq. per $100 \mathrm{~g}$. of soil. Its mean bulk-density is around 1.54, somewhat 
high on account of the presence of pebbles in the surface layer. The soil $\mathrm{pH}$ was brought to around 6.8 by liming.

At a soil:water potential of around $100-\mathrm{cm}$. water-suction, or approximately -10 joules per kilogram, the upper $30 \mathrm{~cm}$. of soil retain 40 -percent water by volume. As the wilting point appears to be around 24 percent by volume, the available water-holding capacity for the upper 30 $\mathrm{cm}$. would be around $5 \mathrm{~cm}$. of water.

Two tobacco experiments were established on January 29,1964 , in a completely randomized design replicated three times, where three irrigation regimes constituted the experimental treatments. Variety P.R. 1-60 was grown in one experiment and a mosaic-resistant line in the other.

After 4 weeks growing on flats with Vita-Bands the seedlings were transplanted to the experimental plots. Vita-Bands are asphalted cardboard divisions used to separate individual seedlings growing on flats. It is a trade name.

About 110 g. of 10-10-8 fertilizer was applied per plant at planting. The plants were set about $45 \mathrm{~cm}$. apart in rows on top of the ridge. These rows were $60 \mathrm{~cm}$. apart along both sides of an irrigation furrow, and $90 \mathrm{~cm}$. apart otherwise. Thus, there were $150 \mathrm{~cm}$. between furrows. This alternate distance arrangement between rows $(60$ and $90 \mathrm{~cm}$.), allowing a distance of $150 \mathrm{~cm}$. between furrows, permitted the irrigation stream to run close to the active root zone of the plants on one side of the tobacco rows. The planting distance allowed for 28,650 plants per hectare $(11,280$ plants per cuerda). This is around 30-percent more than the standard plant population.

Insect control was carried on as needed with 15-percent Parathion, 50percent wettable. Weed control was practiced manually with hoes, twice before the crop shaded almost completely the soil.

Weather data were recorded as air temperature, air humidity, wind movement, and solar energy. Daily pan evaporation and precipitation were also recorded near the experimental site.

All treatments were furrow-irrigated after planting on a previously leveled field. From then on, differential irrigation was applied on the basis of the electrical resistance reading of calibrated soil-moisture plugs (2) buried at 10- and 40-cm. soil depths on each experimental unit. The three irrigation regimes were: 1 , Irrigated whenever either the 10 - or the $40-\mathrm{cm}$. plug (two out of three replicated stations) reached around $2,000 \mathrm{ohms}$, equivalent to a soil: water potential of -70 joules per kilogram; 2 , irrigated whenever either plug reached $6,000 \mathrm{ohms}$, equivalent to around -500 joules per kilogram; and 3, no irrigation.

About $3.7 \mathrm{~cm}$. of water were applied to the frequently irrigated plots, 
and about $5 \mathrm{~cm}$. were applied to the less frequently irrigated plots. The irrigation water had an electrical conductivity of around 1.2 mmhos per $\mathrm{cm}$., a chloride ion content of around 130 p.p.m., and around 140 p.p.m. of sulfates. It contained about 2, 24, and 30 p.p.m. of potassium, calcium, and magnesium, respectively.

Weekly leaf primings of both varieties were started 53 days after planting. Seven primings were made in all. The plants were topped after general inflorescence emergence, midway between the first and the last primings. Suckering was practiced as necessary. After each priming, the green tobacco leaves were air-cured in a conventional barn for 4 weeks. They were then weighed and graded according to the USDA standards for U.S. Type 46.

Representative samples of the cured leaves, by experimental units, were taken for chemical analysis of potassium, calcium, chlorides, and ash by

TABLE 1.-The mean tobacco yield, averaged from $s$ replications, of varieties P.R. 1-60 and $X-18$, as $a$ result of the irrigation regime

\begin{tabular}{l|c|c}
\hline \multicolumn{1}{c|}{ Irrigation regime } & P.R. 1-60 & X-13 \\
\hline & Kilograms per hectares' \\
Frequent irrigation & $3,070.6$ & $2,040.4$ \\
Intermediate irrigation & $3,041.5$ & $1,933.9$ \\
No irrigation & $2,438.3$ & $1,149.1$ \\
Yield increase as a result of irrigation, in percent & 25 & 73 \\
\hline
\end{tabular}

11 kilogram per hectare is equal to $0.00892 \mathrm{cwt}$./acre.

percent. Representative green-leaf samples were also obtained on the harvest date for moisture content of the leaf.

\section{EXPERIMENTAL RESULTS}

Table 1 indicates the tobacco yield (mean of three replications) of the varieties P.R. 1-60 and X-13 by irrigation regimes. The mean accumulated yield with primings, as a result of the irrigation regime, is also indicated in figures 1 and 2, together with the rainfall of the week preceding each priming.

It may be observed from table 1 that irrigation, irrespective of applied frequency, exhibited a positive effect on the yield of P.R. 1-60 and X-13 filler tobacco. The former variety was a better yielder in all irrigation regimes. As shown in table 2 it exhibited a significant response to irrigation, although only slight, nonsignificant differences in tobacco yields were shown as a result of the irrigation frequency. On the other hand, table 2 indicates that for variety $\mathrm{X}-13$ all irrigation treatments exhibited a highly significant effect on yield. 
A high incidence of mosaic on P.R. 1-60, not related to irrigation treatment, and which persisted from the 4th priming on, introduced an adverse though nonuniform effect among replicates, resulting in a high sum of squares for "error" in the analysis of variance.

Table 3 shows a relation of the mineral and chloride composition of the

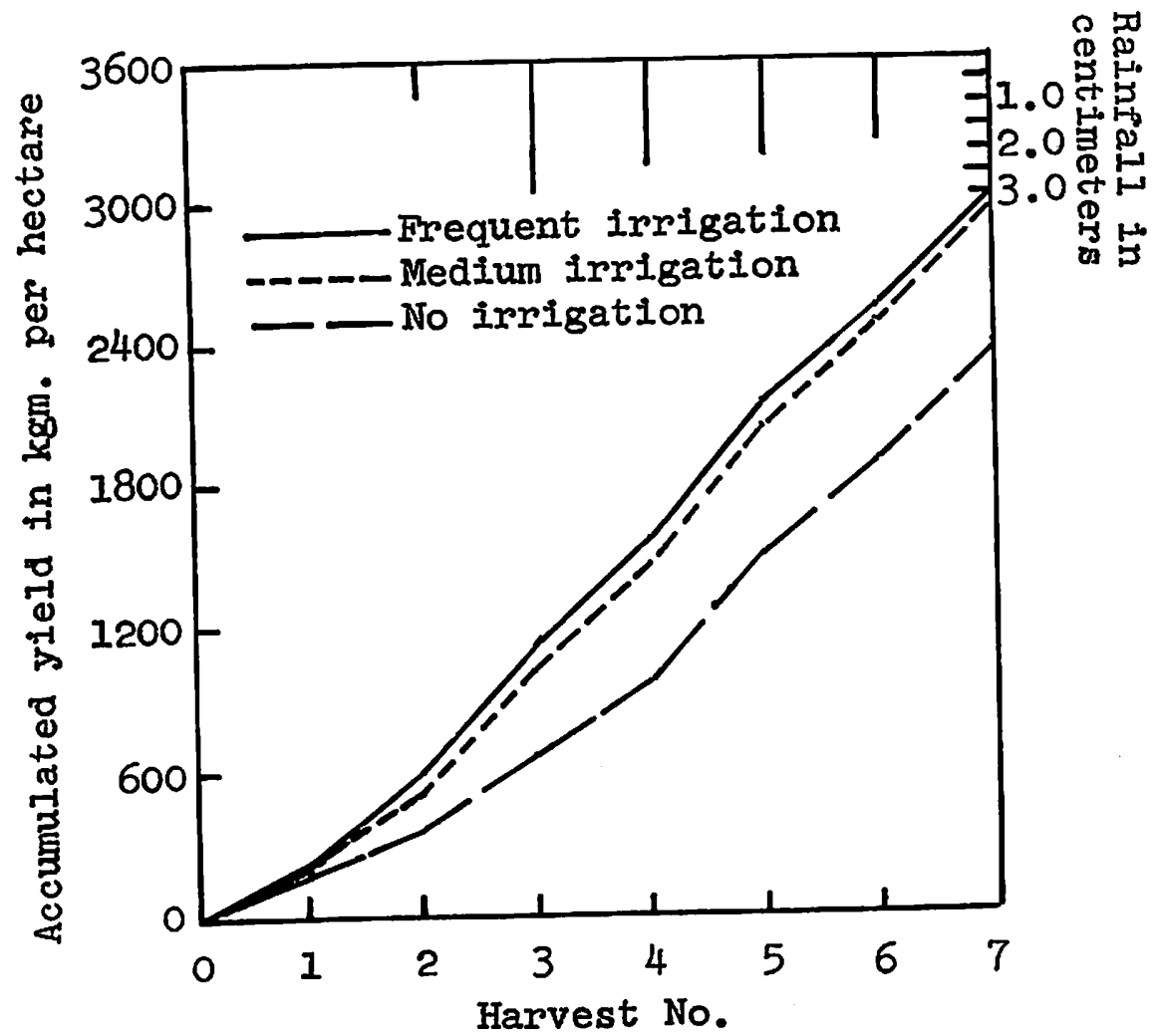

Frc. 1.-Mean accumulated yield of tobacco variety P.R. 1-60 with primings.

cured tobacco leaves of both varieties, averaged for the seven primings. The moisture content of the green leaf is also indicated.

An attempt was made to trace back to plant nutrition the yield-response of the two tobacco varieties to irrigation, in light of the possible injury which may have been exhibited on the mineral uptake of the mosaicaffected variety. The yield of each of the nine experimental units of the two experiments was related to the ash, potassium, chloride, and greenleaf moisture content along the seven primings, by regression analysis (table 4).

Figures 3 to 7 present some of the regression data that were statistically significant. 


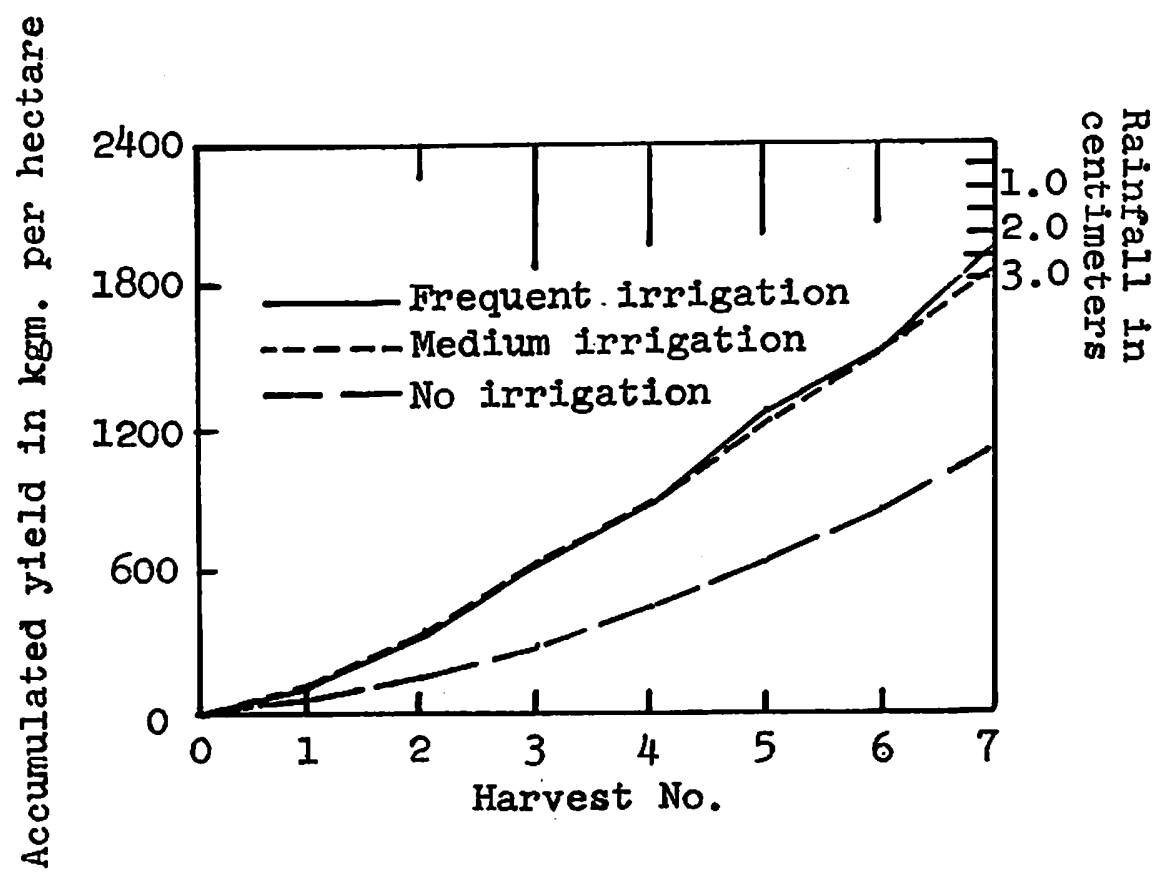

Fig. 2.-Mean accumulaled yield of tobacco variety $\mathrm{X}-13$ with primings.

TABLE 2.-Analysis of variance for the vield of varieties P.R. $1-60$ and $X-18$ grown in 2 completely randomized experiments ${ }^{1}$

\begin{tabular}{l|c|c|c|c}
\hline \multicolumn{1}{c|}{ Source } & D.f. & Sum of squares & Mean square & F Value' \\
\cline { 2 - 3 } & & P.R. 1-60 & & \\
Total & 8 & 97.7274 & & \\
Irrigation & 1 & 60.6808 & 60.6808 & $9.87^{*}$ \\
Irrigation frequency & 1 & 0.1408 & 0.1408 & 0.14 \\
Error & 6 & 36.9058 & &. \\
Total & & $X-13$ & & \\
Treatment & 8 & 118.2174 & & \\
Error & 2 & 113.0244 & 56.5122 & $65.29^{* *}$ \\
\hline
\end{tabular}

$1 *$ Significant at the 5-percent level $(F=5.15) ; * *$ significant at the 1 -percent level $(F=10.92)$.

The results shown graphically in figure 3 , and also in table 4, suggest that, while P.R. 1-60 tobacco yields by primings were related in a highly significant way to the ash content of the leaves, the $X-13$ tobacco yields had no significant relationship with ash. On the other hand, the $F$ value 
TABLE 3-Mineral and chloride composition of the cured tobacco leaves and their moisture content at harvest, by experimental units

\begin{tabular}{|c|c|c|c|c|c|c|c|c|c|}
\hline \multicolumn{10}{|c|}{ Percentage composition 1} \\
\hline \multirow{4}{*}{ Nutrient } & \multicolumn{9}{|c|}{ Irrigation regime } \\
\hline & \multicolumn{3}{|c|}{ Frequent } & \multicolumn{3}{|c|}{ Medium } & \multicolumn{3}{|c|}{ None } \\
\hline & \multicolumn{3}{|c|}{ Replication } & \multicolumn{3}{|c|}{ Replication } & \multicolumn{3}{|c|}{ Replication } \\
\hline & 1 & 2 & 3 & 1 & 2 & 3 & 1 & 2 & 3 \\
\hline \multicolumn{10}{|c|}{ Variety $P . R .1-60$} \\
\hline $\begin{array}{l}\mathrm{K} \\
\mathrm{Ca} \\
\mathrm{Cl} \\
\text { Ash } \\
\text { Water }\end{array}$ & $\begin{array}{r}2.11 \\
3.22 \\
4.40 \\
18.46 \\
89.60\end{array}$ & $\begin{array}{r}2.87 \\
3.05 \\
4.00 \\
18.53 \\
90.10\end{array}$ & $\begin{array}{r}2.33 \\
3.49 \\
4.30 \\
19.28 \\
90.40\end{array}$ & $\begin{array}{r}2.74 \\
3.12 \\
4.00 \\
18.78 \\
91.60\end{array}$ & $\begin{array}{r}2.18 \\
3.37 \\
4.10 \\
18.86 \\
90.50\end{array}$ & $\begin{array}{r}2.45 \\
3.47 \\
4.00 \\
19.18 \\
91.20\end{array}$ & $\begin{array}{r}1.76 \\
3.07 \\
3.90 \\
17.36 \\
87.90\end{array}$ & $\begin{array}{r}1.73 \\
3.24 \\
3.80 \\
17.39 \\
89.40\end{array}$ & $\begin{array}{r}2.20 \\
3.31 \\
3.60 \\
18.33 \\
89.40\end{array}$ \\
\hline \multicolumn{10}{|c|}{ Variety $X-1 s$} \\
\hline $\begin{array}{l}\mathbf{K} \\
\mathrm{Ca} \\
\mathrm{Cl} \\
\text { Ash } \\
\text { Water }\end{array}$ & $\begin{array}{r}2.08 \\
3.15 \\
3.60 \\
17.48 \\
88.10\end{array}$ & $\begin{array}{r}2.76 \\
2.88 \\
3.30 \\
17.83 \\
88.80\end{array}$ & $\begin{array}{r}1.88 \\
3.36 \\
3.70 \\
17.91 \\
88.50\end{array}$ & $\begin{array}{r}1.71 \\
3.47 \\
3.60 \\
17.79 \\
89.10\end{array}$ & $\begin{array}{r}1.66 \\
3.29 \\
3.70 \\
16.97 \\
88.70\end{array}$ & $\begin{array}{r}1.93 \\
3.44 \\
3.20 \\
17.49 \\
88.40\end{array}$ & $\begin{array}{r}1.38 \\
3.16 \\
3.10 \\
16.47 \\
87.70\end{array}$ & $\begin{array}{r}1.50 \\
3.12 \\
3.60 \\
17.40 \\
87.80\end{array}$ & $\begin{array}{r}1.46 \\
3.29 \\
3.60 \\
17.38 \\
87.90\end{array}$ \\
\hline
\end{tabular}

1 Mean of 7 primings.

TABLE 4-Regression data pertaining to the nutritional composition of tobacco varieties $P . R$. 1-60 and $X-18$ as related to the corresponding yields of $\gamma$ primings; the regression data of ash and potassium on moisture-percent of the leaf are also given

\begin{tabular}{|c|c|c|c|c|c|c|}
\hline \multirow{2}{*}{ Correlation } & \multicolumn{2}{|c|}{ Regression coefficient } & \multicolumn{2}{|c|}{ Correlation coefficient } & \multicolumn{2}{|c|}{ F Value' } \\
\hline & P.R. 1-60 & $\mathrm{X}-13$ & P.R. 1-60 & $\mathrm{X}-13$ & P.R. $1-60$ & $\mathrm{X}-13$ \\
\hline Yield v8. ash & 4.77 & 4.61 & 0.94 & 0.55 & $58.38^{* *}$ & 2.97 \\
\hline Yield v8. K. & 5.49 & 6.13 & .61 & .67 & 4.14 & $5.85^{*}$ \\
\hline Yield v8. Cl & 7.44 & 2.09 & .52 & .12 & 2.53 & 0.11 \\
\hline Yield vs. leaf moisture & 2.28 & 6.40 & .72 & .81 & $7.52^{*}$ & $13.43^{* *}$ \\
\hline Ash v8. leaf moisture & .51 & .53 & .81 & .57 & $13.38^{* *}$ & 3.37 \\
\hline $\mathrm{K}$ v8. leaf moisture & .65 & .45 & .73 & .52 & $8.12^{*}$ & 2.60 \\
\hline
\end{tabular}

1 * Significant at the 5-percent level; ** significant at the 1-percent level. 


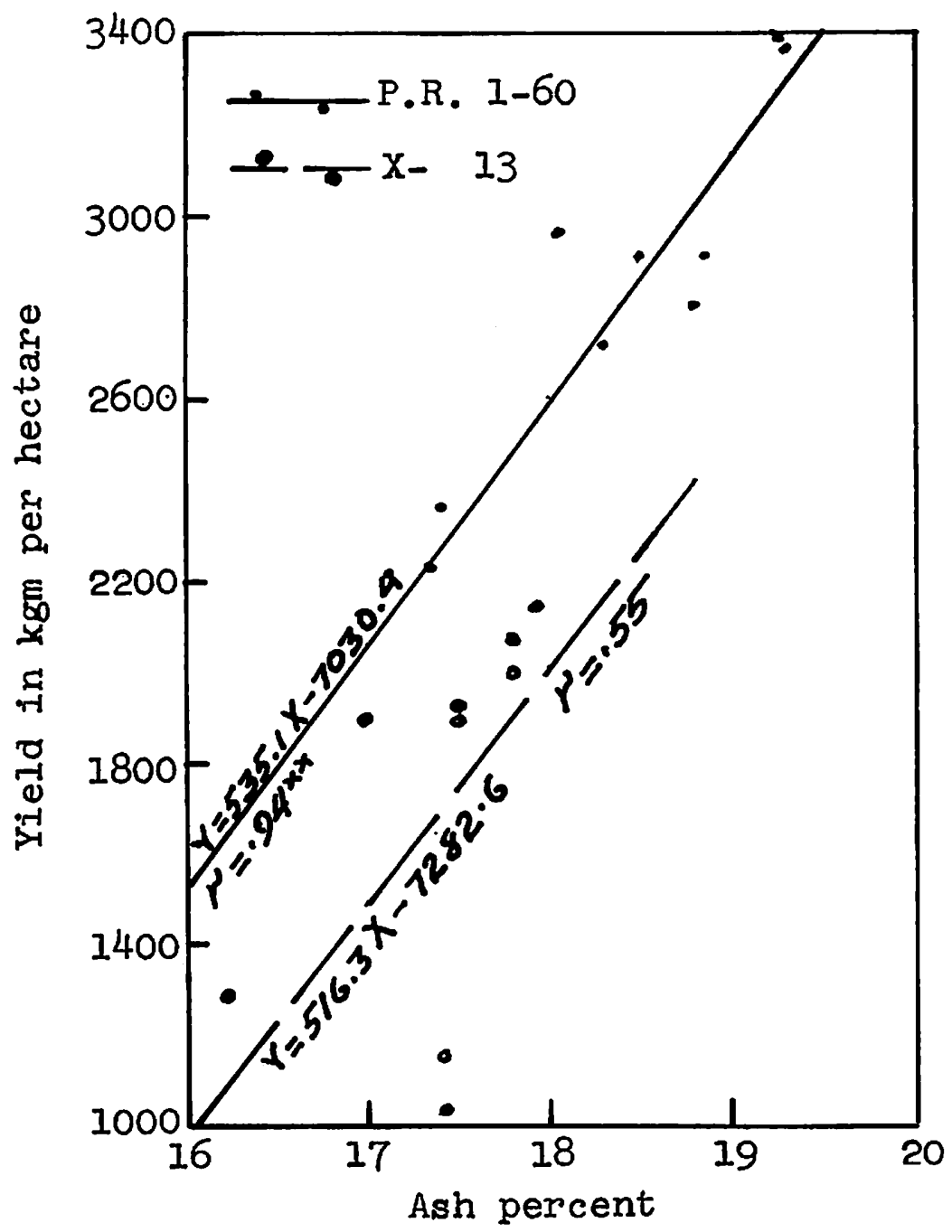

Fig. 3.-Yield by primings of the 9 experimental units of tobacco varieties P.R. 1-60 and X-13 as related to the ash-percent of the leaf.

of the correlation between yield and moisture content of the leaf at harvest of X-13 was higher than that of P.R. 1-60 (figure 5 and table 4).

Moreover, the regression of the ash content on leaf moisture was highly significant for P.R. 1-60 (at the 1-percent level), but no statistically significant relationship in this respect was associated with X-13 (fig. 6 and table 4). However, potassium was slightly better related to the weekly 


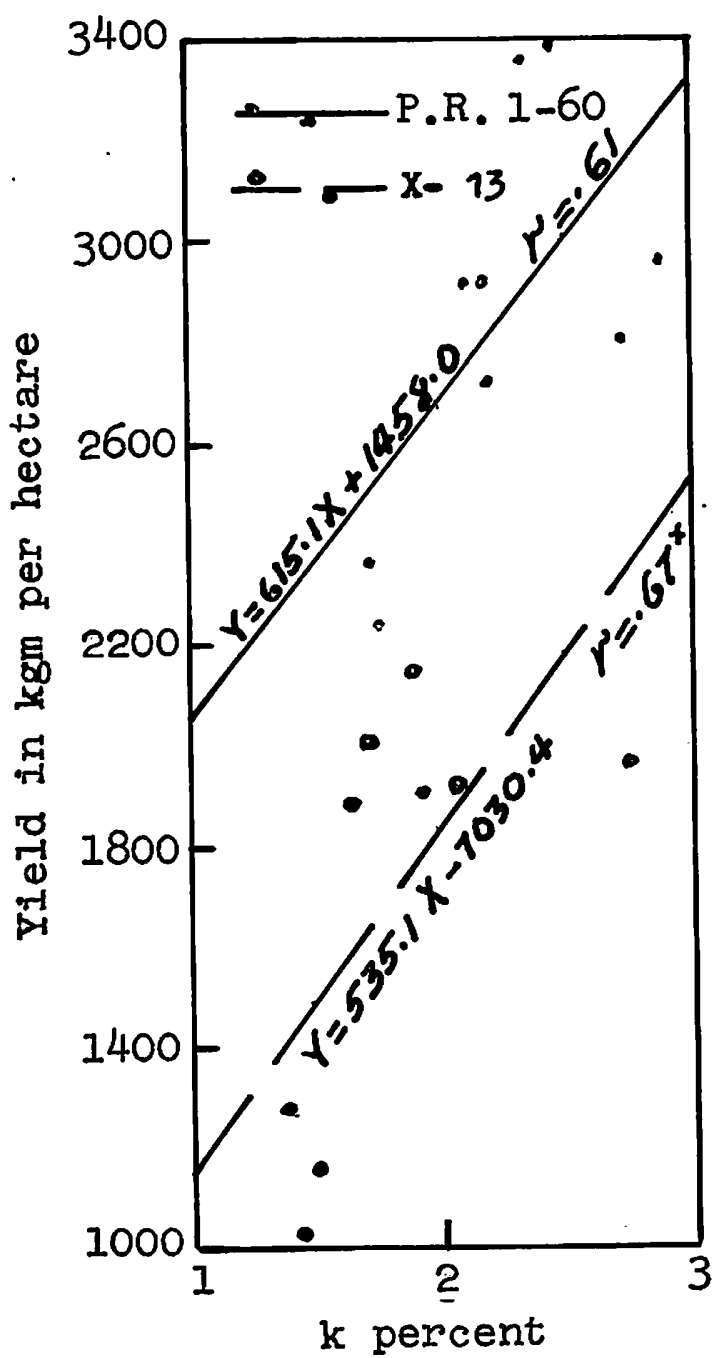

Fra. 4.- Yield by primings of the 9 experimental units of tobacco varieties P.R. 1-60 and X-13 as related to the potassium-percent of the leaf.

yields of X-13 (at the 5-percent level) than was P.R. 1-60 (fig. 4 and table 4 ), though the situation was opposite with respect to potassium as a function of the moisture content of the leaf (fig. 7 and table 4). In general, the mineral composition of the mosaic-affected variety (P.R. 1-60) exerted a significant limiting effect on yield, not apparent for X-13. 


\section{DISCUSSION}

The results of this study point to some nutrient:composition:yield relationships that have a bearing on tobacco production. These relationships possibly play a leading role on the magnitude of the yield range of a given



Frg. 5.-Yield by primings of the 9 experimental units of tobacco varieties P.R. $1-60$ and $X-13$ as related to the moisture-percent of the leaf.

variety in response to the existing ecological and physiological conditions under which the plant grows. Table 1 shows the nature of the yield differences of two tobacco varieties under similar management and environmental conditions. However, such differences were limited by the fact that variety P.R. 1-60 experimented a physiological injury as a result of the incidence of mosaic. A masking effect of this disease may have caused nonsignificant difference in yield of P.R. 1-60 as a result of irrigation frequency. The disease-free variety (X-13) showed response not only to irriga- 
tion frequency, but more convincingly to irrigation as compared with no irrigation ( 3 times as much).

A fact that may have caused irrigation frequency not to show up plainly was the somewhat light but well-spaced precipitation (see figs. 1 and 2).

As mosaic made a progressive, and at the same time nonuniform appearance on P.R. 1-60, the yield variability among experimental units, irrespective of treatment or replication, became so marked that from the fifth

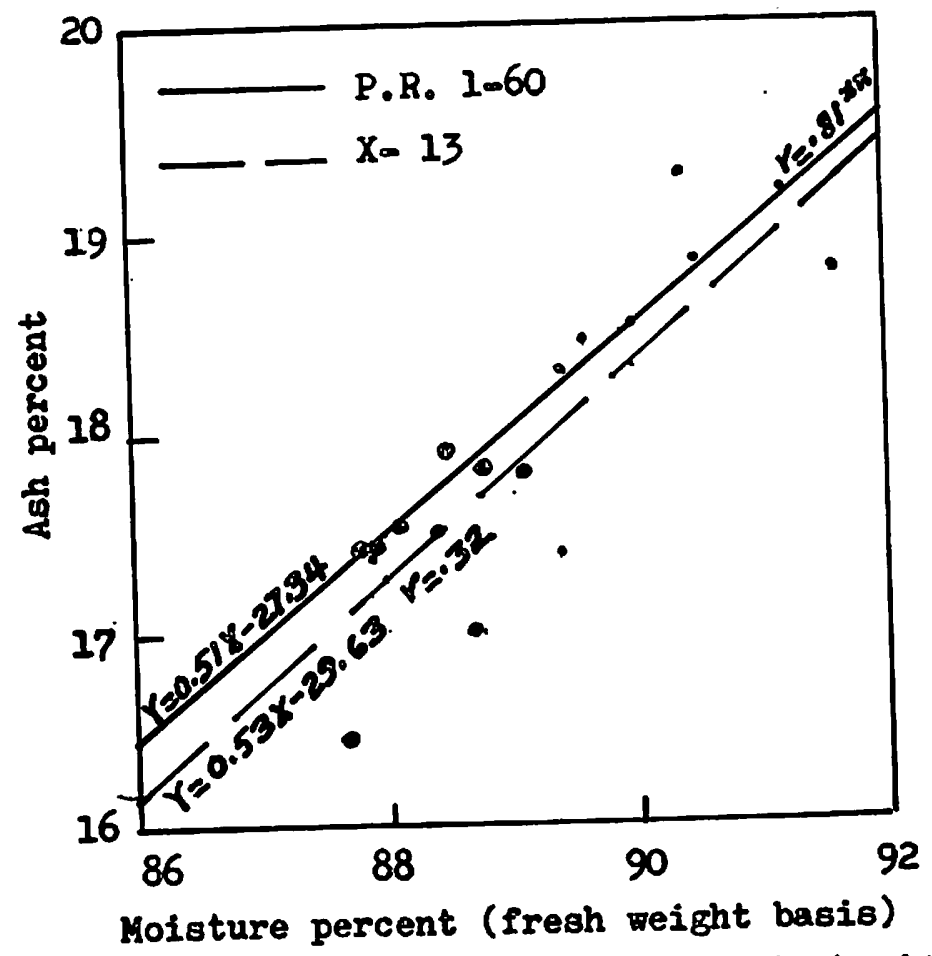

Fic. 6.-Moisture-percent by primings of the 9 experimental units of tobacco varieties P.R. 1-60 and X-13 as related to the ash-percent of the leaf.

priming on mean yield differences due to irrigation were less and less apparent. This fact does explain the high sum of squares for error for P.R. 1-60 in contrast to $\mathrm{X}-13$ (table 2). One can realize, therefore, the less evident response to irrigation by the higher yielder variety (P.R. 1-60).

The highly significant linear regression of yield on ash-percent (fig. 3), as the yields of P.R. 1-60 were greater on some of the primings, implies that the adverse effect of mosaic on the yields of the latter primings was intimately related to deficient mineral uptake. The disperse relationship between yield and ash for X-13 suggests that mineral uptake did not exert 
a restraining effect on this mosaic-free variety. The effect of irrigation treatment is possibly tied in, in view of the contrasting results obtained when analyzing the regression of yield on moisture-percent of the green leaves, whose $\mathrm{F}$ values also appear on table 4 . It is interesting to note also that the regression of the X-13 variety yields on leaf moisture was highly significant (at the 1-percent level) in spite of the poor relationships that both leaf moisture and yield showed with the ash-percent of this variety. The F-value was higher than for P.R. 1-60, in spite of the fact that both

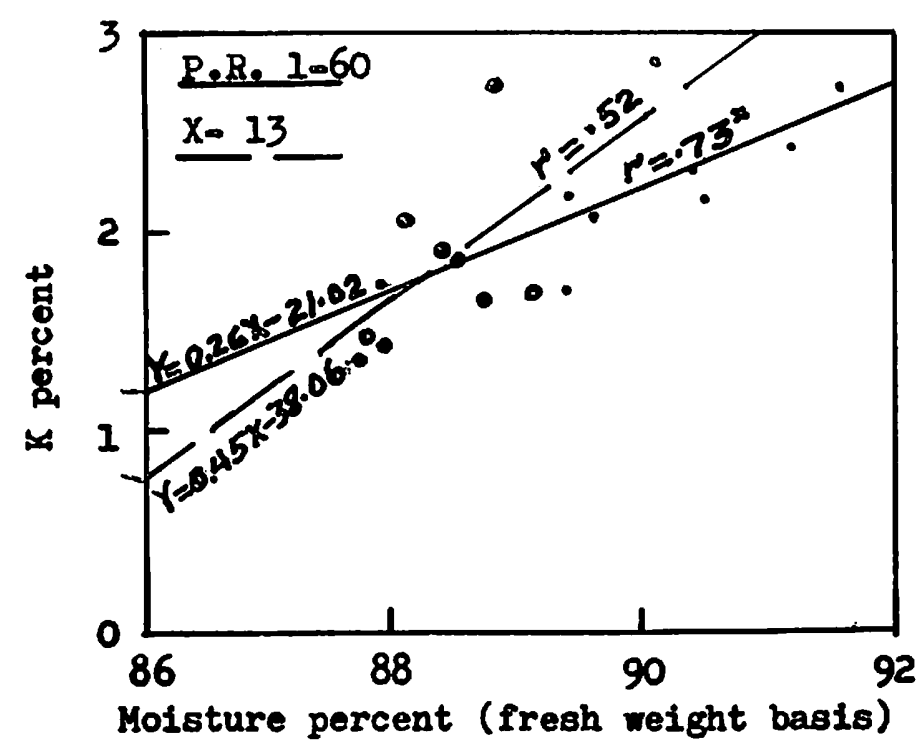

Fra. 7.-Moisture-percent by primings of the nine experimental units of tobacco varieties P.R. 1-60 and X-13 as related to the potassium-percent of the leaf.

leaf moisture and yield were correlated very significantly with ash-percent of the latter variety.

The ash content of the tobacco leaf is known to be inversely related to combustibility. Yet the commercial grading of both varieties, made after the leaves were cured, resulted in a better grading of the higher ash-content leaves. However, the greatest differences are no more than 2 percent, and it is doubtful that such small differences may cause variations in combustibility. Of greater concern is the high chloride content of the leaves of both varieties under all treatments, though especially so on P.R. 1-60 with frequent irrigation. The undesirable effect that chloride content may exert on the tobacco leaves has been discussed elsewhere.

Outside of any value that regression analysis may have in this study in predicting yield from mineral content of leaves or mineral content from 
moisture content of leaves, the regression coefficients (slopes) appear to imply the following:

1. The yield-mineral composition relationship maintains a nearly constant relation, irrespective of variety or physiological injury, as suggested from the almost parallel slopes in figures 3 and 4.

2. If leaf turgidity can be considered as greatly dependent on soil:water potential, and therefore on irrigation treatment in this study, it can be concluded from figure 5 that the mosaic-free variety, X-13, made a far more efficient use of irrigation, in terms of yield, as suggested by the steeper slope of the line representing this variety. Figures 6 and 7 also suggest that mineral content was enhanced with irrigation slightly more in the mosaicfree variety (X-13), as indicated by the steeper slopes of the lines representing this variety on both figures.

\section{SUMMARY}

Two irrigation experiments with cigar-filler tobacco were conducted on the Gurabo Substation Experimental Farm in a field graded for furrow irrigation. The objective was to evaluate the effect of different irrigation frequencies on the yield and quality of two tobacco varieties, P.R. 1-60 and a mosaic resistant line, X-13.

Irrigation significantly increased the yield of varieties $X-13$ and P.R. 1-60. However, in spite that, the yield of P.R. 1-60 tobacco was greater under all treatments; the former showed about three times as much response to irrigation as compared with no irrigation. This variety (X-13) was also responsive to the irrigation level, in spite of light, but well-spaced precipitation between primings. A high incidence of mosaic on P.R. 1-60, which appeared since the fifth priming, probably masked a better response of this variety to irrigation.

In an attempt to trace back to plant nutrition the injury caused by mosaic on P.R. 1-60 yields, a linear regression of yield on mineral content of the leaves was carried out, using the individual yield data by experimental units. From an analysis of these data, it seems likely that mosaic caused a yield-limiting effect on P.R. 1-60 as a result of adversely affecting the uptake of minerals by the plant. On the other hand, when observing the highly significant regression of $\mathrm{X}-13$ yields on the moisture content of the leaves and at the same time comparing its regression coefficient (slope) with the corresponding one in variety P.R. 1-60, one may conclude that X-13 made a more efficient use of irrigation which was expressed in greater yield response.

\section{RESUMEN}

En la Subestación de Gurabo se realizaron dos experimentos con riego incluyendo dos variedades de tabaco para tripa. El objetivo fue evaluar el 
efecto de tres regímenes o frecuencias de riego sobre el rendimiento y calidad de las variedades P.R. 1-60 y X-13, ésta última resistente al mosaico.

El riego aumentó el rendimiento de ambas variedades de tabaco. Sin embargo, a pesar de que el rendimiento de la variedad P.R. 1-60 fue mayor a todos los niveles de riego, el de la X-13 fue casi tres veces más con riego que sin el mismo. Contrario a la P.R. 1-60, la X-13 respondió también a la frecuencia con que se aplicó el riego, a pesar de haberse registrado alguna lluvia bien espaciada.

En un intento por investigar el efecto adverso del mosaico sobre el rendimiento de la variedad P.R. 1-60, se investigó la regresión lineal de la producción en el contenido de ciertos minerales en la hoja de tabaco. Del análisis de los datos experimentales se desprende que el efecto adverso del mosaico sobre la producción de la P.R. 1-60 pudo ser el resultado de la influencia de dicha enfermedad virosa en cuanto a la absorción de minerales por las plantas. Por otro lado, el alto valor significativo de la regresión de producción por parcelas de la X-13 en el contenido de humedad de las hojas sugiere una relación íntima entre la producción y el riego, respecto a esta variedad. La marcada pendiente de su coeficiente de regresión, comparada con la correspondiente a la variedad P.R. 1-60, sugiere además que la X-13 usó del riego con una mayor eficiencia.

\section{LITERATURE CITED}

1: Acosta Matienzo, A., González Molina, C., and Samuels, G., Response of filler tobacco crop to different planting dates, J. Agr. Univ. P.R. 50 (3): 161-73, 1966.

2. Capiel, M., Evaluation of the intrinsic performance of electrical-resistance units for measuring soil moisture, J. Agr. Univ. P.R. 49 (3): 350-67, 1965.

3. Manzano, M. A., En torno al tabaco; Instituto del Tabaco de Puerto Rico, Bol. 2, 1941.

4. Parks, W. L. and Safley, L. M., The effect of irrigation and nitrogen upon the yield and quality of dark tobacco, Tenn. Agr. Expt. Sta. Bull. 394, 1965.

5. Ramakrishna Kurup, C. K., Sastry, A. S., and Subba Rao, D., Further studies on the influence of soil and irrigation water on the chemical composition and quality of cigar tobacco, $J$. Ind. Soc. Soil Sci. 10: 237-42, 1962. 